\title{
PENGENDALIAN PENCEMARAN \\ UDARA LINTAS BATAS DALAM PERSPEKTIF PERJANJIAN INTERNASIONAL
}

\author{
Suparto Wijoyo \\ Fakultas Hukum Universitas Airlangga, suparto_wijoyo@yahoo.com
}

\begin{abstract}
International treaties in the field of protection of atmosphere and trans-boundary air pollution that qualified as 'soft law' and 'hard law' legal document has developed since 1919 until at present. From the Study on the International treaties, it can be known that the global community has strong commitment to the problem of protection of atmosphere and trans-boundary air pollution. Unfortunately, it can be concluded, that those international treaties is so fragmented and therefore, is difficult to be implemented comparing with instrument of international environmental law in general.
\end{abstract}

Keyword: international treaties, protection of atmosphere, transboundary air pollution

\begin{abstract}
Abstrak
Perjanjian Internasional mengenai perlindungan atmosfer dan pencemaran udara lintas batas yang dikategorikan dalam kerangka hukum 'soft law'dan 'hard law'telah berkembang pesat sejak 1919 hingga sekarang. Dari kajian terhadap perjanjian internasional tersebut diketahui bahwa masyarakat global di seluruh dunia memiliki komitmen untuk menyelesaikan masalah yang terkait dengan perlindungan terhadap lapisan atmosfer dan pencemaran udara lintas-batas. Namun rupanya instrument-instrumen tersebut sifatnya masih sektoral sehingga menimbulkan kesulitan dalam pengimplementasiannya, terlebih jika diharmonisasikan dengan intrumen internasional hukum lingkungan secara umum.
\end{abstract}

Kata Kunci: Perjanjian internasional, perlindungan terhadap atmosfer, pencemaran udara lintas-batas

\section{Pendahuluan}

Inventarisasi terhadap "international
environmental legal instruments"
menemukan lebih dari 500 perjanjian
internasional mengenai lingkungan. ${ }^{1}$

${ }^{1}$ Maria Hartiningsih, loc.cit. Daud Silalahi,
Perjanjian-perjanjian internasional di bidang perlindungan atmosfer dan pencemaran

"Sustainable Development in Indonesia: National, Regional and International Environmental Law", Indonesian Journal of Environmental Law, Edition I, August 1996, h. 43-50. Kompas, Implementasi Johannesburg Untuk Indonesia: Supaya Tidak Mengaisi Remah-remah, 22 November 2002. Kompas, Implementasi Johannesburg Untuk Indonesia: Pelajaran Dari WSSD, 22 November 2002. 
udara lintas batas yang dikualifikasi dalam kerangka dokumen hukum "soft law" maupun "hard law" telah berkembang pesat sejak tahun 1919 sampai sekarang. ${ }^{2}$

Dari perjanjian-perjanjian internasional yang diinventarisirdiketahui betapabesarnya komitmen komunitas dunia pada masalah perlindungan atmosfer dan pengendalian pencemaran udara lintas batas. Namun, perjanjian-perjanjian internasional yang ada dinilai terlalu fragmental dan sulit untuk diimplementasikan sebagaimana halnya dengan instrumen hukum lingkungan internasional pada umumnya.

Kesepakatan internasional mengenai lingkungan selama ini dirasakan belum dapat dilaksanakan secara efektif. WSSD di Johannesburg tahun 2002 merasa perlu untuk menemukan cara-cara mengoptimalkan penerapan perjanjian internasional di bidang lingkungan dalam "Plan of Implementation" terutama di bagian "Means of Implementation" guna menghadapi dua tantangan besar: kehidupan yang lebih baik dari semua manusia dan melindungi lingkungan yang menopang kehidupan Bumi. ${ }^{3}$

Perjanjian-perjanjian internasional dalam konteks perlindungan atmosfer maupun pengendalian pencemaran udara

\footnotetext{
${ }^{2}$ Edith Brown Weiss, Environmental Change and International Law, United Nations University Press, Tokyo, 1992, h. 479-490. La Ode Muhamad Syarif, op.cit., h. xxix-xxxii. Mercedes Fernandes Armenteros, An Overview of the Marrakech Agreement, ELNI, 2/2001.

3 Maria Hartiningsih, loc.cit. Kompas, Pertemuan Kepala Negara Dimulai, WSSD Dikhawatirkan Menjadi Rio Minus 10, 2 September 2002. Kompas, Kerja Sama Untuk Dunia yang Lebih Baik, 27 Agustus 2002. Surya, Hujan Merata Tapi Tetap Panas, 14 November 2002. Surya, Efek Gas Rumah Kaca, 14 November 2002.
}

lintas batas yang perlu mendapatkan kajian mendalam untuk diimplementasikan dan dikembangkan lebih lanjut di Indonesia adalah: (i) "Vienna Convention" dan "MontrealProtocol", (ii) "The Hague Declaration" dan "The Noordwijk Declaration", (iii) UN-FCCC dan "Kyoto Protocol", serta (iv) Program Lingkungan ASEAN dan “LRTAP Convention”, 1979.

\section{Vienna Convention (1985) dan Montreal Protocol (1987, 1990 dan 1992)}

Pada tanggal 22 Maret 1985 di Wina, Austria telah diterima Vienna Convention on the Protection of the Ozone Layer ("Vienna Convention") dan pada tanggal 16 September 1987 di Montreal, Kanada disetujui Montreal Protocol on Substances That Deplete the Ozone Layer as Adjusted and Amended by the Second Meeting of the Parties London, 27-29 June 1990 ( "Montreal Protocol"). Kedua instrumen internasional ini diratifikasi Indonesia pada tanggal 13 Mei 1992 dalam Keputusan Presiden No. 23 Tahun 1992 tentang Pengesahan Vienna Convention for the Protection of the Ozone Layer dan Montreal Protocol on Substances That Deplete the Ozone Layer as Adjusted and Amended by the Second Meeting of the Parties London, 27-29 June 1990.

Persidangan ke-4 Negara-negara Anggota Vienna Convention pada tanggal 23-25 November 1992 di Copenhagen, Denmark menghasilkan perubahan Montreal Protocol: Montreal Protocol on Substances That Deplete the Ozone Layer, Copenhagen, 1992. Indonesia pada tanggal 23 Juni 1998 meratifikasinya melalui Keputusan Presiden 
No. 92 Tahun 1998 tentang Pengesahan Montreal Protocol on Substances That Deplete the Ozone Layer, Copenhagen 1992 (Protokol Montreal Tentang Zat-zat yang Merusak Lapisan Ozon, Copenhagen 1992).

Vienna Convention merupakan kesepakatan internasional di bidang perlindungan lapisan ozon yang dijabarkan dalam Montreal Protocol mengenai zat-zat perusak lapisan ozon atau ODS (ozone-depleting substances). Ratifikasi Vienna Convention dan Montreal Protocol bertujuan untuk: melindungi lapisan ozon, membuat jadwal penghapusan produksi ODS secara bertahap, dan membatasi konsumsi ODS nasional sesuai dengan kesepakatan para pihak pada tingkat global.

\section{Article 2 Paragraph 1 Vienna} Convention menetapkan kewajiban umum bagi negara-negara anggota untuk mengambil inisiatif perlindungan lapisan ozon. Berlakunya Vienna Convention mencerminkan reaksi internasional terhadap penipisan lapisan ozon akibat produksi dan konsumsi “chlorofluorocarbons" (CFCs). Indonesia mencanangkan penghapusan pemakaian ODS pada akhir tahun $1997 .{ }^{4}$

Montreal Protocol menetapkan

${ }^{4}$ Kantor Menteri Negara Lingkungan Hidup dan United Nations Development Programme (UNEP), Kumpulan Peraturan Pemerintah Republik Indonesia Tentang Perlindungan Lapisan Ozon dan Penghapusan Bahan-bahan Perusak Lapisan Ozon, Jakarta, 1999, h. iii. Nancy K. Kubasek and Gary S. Silverman, op.cit., h. 264-265. Siti Sundari Rangkuti, Sarana Hukum Pengendalian Pencemaran Udara, Airlangga University Press, Surabaya, 1995, h. 15. Perlu diketengahkan bahwa program penghapusan ODS yang dituangkan dalam Agenda 21 Indonesia sampai saat ini belum diterapkan secara nyata. Terdapat "dualisme" kebijaksanaan penghapusan ODS antara yang ditetapkan dalam Agenda 21 Indonesia dengan "kepentingan sektoral" (Menperindag). pedoman pelaksanaan bagi negara-negara peserta Vienna Convention dalam membatasi produksi ataupun penggunaan ODS. $^{5}$ Dengan jumlah konsumsi perkapita pertahun yang relatif kecil $(0,03 \mathrm{~kg})$, Indonesia termasuk dalam daftar Article 5 Paragraph 1 Montreal Protocol sebagai bagian dari "developing countries" yang mempunyai hak untuk: (i) melakukan penghapusan ODS sepuluh tahun lebih lambat dari negara-negara maju, dan (ii) mendapatkan dana hibah dari Multilateral Fund maupun bantuan pengembangan teknologi bahan pengganti ODS serta alih teknologi dalam proses penghapusan penggunaan ODS. ${ }^{6}$

Dalam Agenda 21 Indonesia dicanangkan penghapusan seluruh pemakaian ODS pada akhir tahun 1997 (berarti lebih awal dari waktu yang ditetapkan Montreal Protocol: tahun 2010). Menurut Keputusan Menperindag No. 110/MPP/Kep/1/1998 tentang Larangan Memproduksi dan Memperdagangkan Bahan Perusak Lapisan Ozon serta Memproduksi dan Memperdagangkan Barang-barang Baru yang Menggunakan Bahan Perusak Lapisan Ozon (Ozone Depleting Substances) (Keputusan Menperindag No. 110 Tahun 1998): ODS maupun barang yang menggunakan ODS boleh diperdagangkan dan dipergunakan sampai 1 Januari 2005. Namun, Keputusan Menperindag No. 410/MPP/Kep/9/1998

\footnotetext{
5 La Ode Muhamad Syarif, op.cit., h. 102. Lihat pula Daniel Murdiyarso, Protokol Kyoto ... op.cit., h. 107-120.

6 Kantor Menteri Negara Lingkungan Hidup dan United Nations Development Programme (UNEP), loc. cit. Kantor Menteri Negara Lingkungan Hidup, op.cit., h. 7-35.
} 
tentang Perubahan Keputusan Menperindag No. 110 Tahun 1998 menyatakan: khusus ODS Metil Bromida No. HS. 2903.30.000 tetap dapat diperdagangkan tanpa batas waktu sepanjang digunakan untuk keperluan karantina dan prapengapalan. Padahal, Keppres No. 92 Tahun 1998 mengatur bahwa Indonesia mempunyai kewajiban untuk menghapuskan ODS Metil Bromida secara bertahap.

Tanggal 27 Januari 1998 ditetapkan pula Keputusan Menperindag No. 111/MPP/ Kep/ll/1998 tentang Perubahan Keputusan Menperindag No. 230/MPP/Kep/1/1997 tentang Barang yang Diatur Tata Niaga Impornya (Keputusan Menperindag No. 111 Tahun 1998). Pada tanggal 3 September 1998 terdapat perkembangan baru dengan diberlakukannya Keputusan Menperindag No. 411/MPP/Kep/9/1998 tentang Perubahan Keputusan Menperindag No. 111 Tahun 1998. Menurut Pasal 5B Keputusan Menperindag ini: khusus untuk barang purna jual lemari es dengan No. HS. 8418.10.000; 8418.21.000, 8418.22.000, dan 8418.29.000 yang memakai CFC-12 tetap diperkenankan mengimpor CFC-12 sampai tanggal 31 Desember 2003 sebanyak-banyaknya 700 ton melalui Importir Terdaftar: PT Dharma Niaga, PT Asomindo Raya dan NV Panca Ratna.

\section{Ratifikasi Vienna Convention dan} Montreal Protocol membawa konsekuensi perlunya ditindaklanjuti pelaksanaannya dalam peraturan perundang-undangan perlindungan lapisan ozon melalui penghapusan ODS. Ternyata terdapat kontradiksi antara kebijaksanaan dasar yang tertuang dalam Agenda 21 Indonesia ${ }^{7}$ dengan ketentuan dari berbagai Keputusan Menperindag. Indonesia belum mengimplementasikan secara nyata konsensus internasional dalam melakukan pengurangan ODS berdasarkan Vienna Convention dan Montreal Protocol.

\section{The Hague Declaration (1989) dan The Noordwijk Declaration (1989)}

The Hague Declaration ditandatangani 24 negara pada tanggal 11 Maret 1989, termasuk Indonesia. Fokus perhatian The Hague Declaration adalah mengenai permasalahan pencemaran udara dan bertujuan: "... the preservation of the air environment”. Deklarasi ini menekankan pada pengembangan prinsip “... new approach to global air pollution" dengan menetapkan mekanisme kerja untuk mendorong negara-negara berkembang mempromosikan pembangunan berkelanjutan. ${ }^{8}$

Sebagai kesepakatan multilateral yang bersifat umum, The Hague Declaration meletakkan arahan dasar bagi negara-negara penandatangan untuk menindaklanjuti substansi muatannya dalam konstalasi internasional tentang perlindungan atmosfer bumi dan pengendalian pencemaran udara global.

Pada tanggal 7 November 1989 dicetuskan The Noordwijk Declaration on Atmospheric Pollution and Climate Change (The Noordwijk Declaration).

\footnotetext{
${ }^{7}$ Kantor Menteri Negara Lingkungan Hidup, op.cit., h. 7-35 sampai dengan 7-40.

${ }^{8}$ La Ode Muhamad Syarif, op.cit., h. 82-83.
} 
Formulasi The Noordwijk Declaration berkarakter komprehensif dan rinci dalam mengakomodasi serta memandang secara serius parahnya kondisi atmosfer maupun perubahan iklim. Pharagraph 1 The Noordwijk Declaration menetapkan bahwa: “...the principle of ecological sustainable development should be implemented by all nations to tackle the problem of climate change and atmospheric pollution". ${ }^{9}$

The Noordwijk Declaration secara spesifik mengedepankan pengakuan masyarakat internasional mengenai pelaksanaan Vienna Convention dan Montreal Protocol. The Noordwijk Declaration tidak menciptakan pendekatan baru tentang tanggung jawab negara terhadap pengendalian pencemaran udara lintas batas. The Noordwijk Declaration lebih memprioritaskan pada jalinan kerjasama antar negara peserta untuk mencapai tujuan utama penghentian ("phase-out") pemakaian ODS sesuai Vienna Convention dan Montreal Protocol. Semua negara peserta didorong untuk segera mengupayakan “... the protection of the planet earth from global warming and climate change" dengan mereduksi emisi GRK. ${ }^{10}$

Secara khusus The Noordwijk Declaration merekomendasikan kepada lembaga-lembaga internasional seperti Multilateral Development Bank (MDB), Bilateral Assistance Programme (BAP)

${ }^{9}$ Ibid., h. 84.

${ }^{10}$ Ibid., h. 85. Sebagai bahan tambahan yang baik adalah: Daniel Murdiyarso, Sepuluh Tahun ... op.cit., h. 12-16. Daniel Murdiyarso, CDM: Mekanisme ... op.cit., h. 73-75. Daniel Murdiyarso, Protokol Kyoto ... op.cit., h. $103-105$. dan organisasi PBB serta badan-badan khususnya untuk memberikan perhatian yang besar pada pendanaan untuk mengatasi perubahan iklim. Direkomendasikan pula bahwa negara-negara berkembang perlu terus-menerus dimobilisir guna menghadapi ancaman "climate change" dalam rangka preservasi atmosfer ${ }^{11}$ yang semakin sejalan dengan UN-FCCC maupun Kyoto Protocol.

\section{UN-FCCC (1992) dan Kyoto Protocol (1997)}

UN-FCCC merupakan hasil UNCED yang memanifestasikan keprihatinan bersama mengenai perubahan iklim dan dampaknya akibat kegiatan manusia yang meningkatkan konsentrasi GRK. ${ }^{12}$ Indonesia meratifikasi dan memberlakukan UN-FCCC melalui Undang-undang No. 6 Tahun 1994 tentang Pengesahan United Nations Framework Convention on Climate Change (Konvensi Kerangka Kerja Perserikatan Bangsa-bangsa Mengenai Perubahan Iklim) (UU Perubahan Iklim).

Pembuatan UN-FCCC bertumpu pada General Assembly Resolution No. 44/228 of 22 December 1989 on the United Nations Conference on Environment and Development dan Resolutions No. 43/53 of 6 December 1988, No. 44/207 of 22 December 1989, No. 54/212 of 21 December 1990 and No. 46/169 of 19 December 1991 on Protection of Global Climate for Present and Future Generations of Mankind. ${ }^{13}$

\footnotetext{
11 Ibid., h. 85-86.

${ }^{12}$ United Nations Environment Programme, op.cit., h. 275. Michael R. Molitor, op.cit., h. 227.

${ }^{13}$ Ibid.
} 
UN-FCCC disusun pula menurut General Assembly Resolution No. 44/206 of 22 December 1989 on the Possible Adverse Effects of Sea Level Rise on Islands and Coastal Areas, Particularly Low-Lying Coastal Areas serta ketentuan lain yang terdapat dalam General Assembly Resolution No. 44/172 of 19 December 1989 on the Implementation of the Plan of Action to Combat Desertification selain Vienna Convention dan Montreal Protocol. ${ }^{14}$

UN-FCCC mengakui secara tegas bahwa kontributor terbesar GRK adalah negara-negara maju. Tujuan akhir yang hendak dicapai UN-FCCC dan setiap perangkat hukum yang disetujui oleh Konferensi Para Pihak adalah tercapainya kestabilan konsentrasi GRK pada tingkat yang dapat mencegah perbuatan manusia yang membahayakan sistem iklim global. ${ }^{15}$

Tindakan yang perlu diambil untuk merealisir tujuan dan melaksanakan UN-FCCC didasarkan pada tujuh prinsip yang ditetapkan Pasal 3 UN-FCCC guna mencapai kestabilan konsentrasi GRK, yaitu:

a. "Common but differentiated responsibilities”: tanggung jawab bersama tetapi berbeda sesuai dengan kemampuan para pihak.

b. "Special consideration for disproportionately burdened developing countries": kebutuhan dan keadaan khusus negara-negara

\footnotetext{
14 Ibid.

15 Ibid., h. 277. Badan Pengendalian Dampak Lingkungan, Himpunan Peraturan Tentang Pengendalian Dampak Lingkungan, Seri X, Jakarta, 1999, h. 145-152.
}

berkembang yang rawan

terhadap perubahan iklim yang harus menanggung beban yang tidak sepadan atau di luar jangkauannya yang perlu mendapatkan perhatian sepenuhnya.

c. "Scientific uncertainty not an excuse for inaction": ketidakpastian ilmiah tidak dapat dijadikan alasan untuk menunda tindakan mengurangi penyebab terjadinya perubahan iklim global.

d. "Cost-effective policy responses": kebijaksanaan yang berkaitan dengan perubahan iklim harus didasarkan pada efektivitas biaya (biaya yang serendah mungkin).

e. "Responses may be carried out cooperatively": kerjasama dengan para pihak yang berkepentingan untuk mengembangkan sistem ekonomi internasional menuju pembangunan berkelanjutan bagi semua peserta konvensi, khususnya negara-negara berkembang dalam menghadapi persoalan perubahan iklim.

f. "Promotion of sustainable development": memprakarsai pelaksanaan pembangunan berkelanjutan untuk menanggulangi perubahan iklim.

g. "No distortion of international trade": larangan pembatasan perdagangan internasional yang terselubung (untuk menanggu-langi perubahan iklim) termasuk yang bersifat unilateral, hendaknya tidak menjadi sarana perbuatan sewenang-wenang atau 
diskriminasi secara tidak bertanggung jawab. ${ }^{16}$

UN-FCCC menekankan agar Para Pihak dalam Konvensi dan yang tercantum pada Annex I maupun Annex II untuk menjalin kemitraan global guna mengurangi emisi GRK. Annex I UN-FCCC berisikan daftar negara maju dan ekonomi transisi dari sistem ekonomi perencanaan terpusat menuju sistem ekonomi pasar. Annex II UN-FCCC memuat nama-nama negara maju yang berkewajiban untuk menyediakan dana pelaksanaan UN-FCCC sebagaimana di bawah ini:

\section{Daftar Negara yang Masuk Dalam} Annex I dan II UN-FCCC

\begin{tabular}{|ll|ll|}
\hline \multicolumn{2}{|c|}{ ANNEX I } & \multicolumn{2}{|c|}{ ANNEX II } \\
\hline Australia & Latvia* & Lustralia & Luxembourg \\
Austria & Lithuania* & Austria & Netherland \\
Belarus* & Luxembourg & Belgium & New Zealand \\
Belgium & Netherlands & Canada & Norway \\
Bulgaria* & New Zealand & Denmark & Portugal \\
Canada & Norway & European Community & Spain \\
Czechoslavakia* & Poland* & Finland & Sweden \\
Denmark & Portugal & France & Switzerland \\
European Community & Romania* & Germany & Turkey \\
Estonia* & Russian Federation* & Greece & United Kingdom \\
Finlandia & Spain & Iceland & of Great Britian and \\
France & Sweden & Ireland & Northem Ireland \\
Germany & Switzerland & Italy & United States of \\
Greece & Turkey & Japan & America \\
Hungary* & Ukraine* & & \\
Iceland & United Kindom of Great & & \\
Ireland & Britai and Northem & & \\
Italy & Ireland & & \\
Japan & United State of America & & \\
& & & \\
\hline
\end{tabular}

Keterangan: *Countries that are undergoing the process of transition to a market economy

Sumber: United NationsEnvironmentProgramme, Handbook of Environmental Law, Hartfordshire SGI 4TP, United Kingdom, t.th., h. 291-292 (diolah).

UN-FCCC berlaku efektif sejak tanggal 24 Maret 1994. Negara-negara maju

\footnotetext{
${ }^{16}$ Disarikan dari Pasal 3 UN-FCCC sebagaimana termuat dalam United Nations Environment Programme, op.cit., h. 277-278.
}

mengucurkan dana untuk penghapusan ODS melalui mekanisme Montreal Trust Fund kepada negara berkembang dengan konsekuensi mengkonsumsi HCFC. Beberapa perusahaan Indonesia telah menerima bantuan dana Montreal Trust Fund melalui UNDP dan UNIDO ("United Nations Industrial and Development Organization”). ${ }^{17}$

Berdasarkan Pasal 3 ayat (3)UN-FCCC: "The parties should take precautionary measures to anticipate, prevent or minimize the causes of climate change and mitigate its adverse effect ...”. Sehubungan dengan hal ini Indonesia membentuk Komite Nasional Iklim dan Lingkungan (KNIL) di bawah koordinasi Menteri Negara Lingkungan Hidup (MENLH). Penghapusan ODS berupa CFC menurut Agenda 21 Indonesia dilakukan atas dasar inisiatif Montreal Protocol. ${ }^{18}$

Penjabaran praktis UN-FCCC dilakukan melalui "The 1997 Kyoto Protocol" (Kyoto Protocol) sebagai produk "Third Conference of Parties" (COP-3) yang diselenggarakan di Kyoto, Jepang pada tahun 1997. Protocol Kyoto secara khusus menetapkan bahwa negara-negara yang tercantum dalam Annex I UN-FCCC mempunyai kewajiban untuk mereduksi emisi GRK sebesar 5\% dalam kurun waktu lima tahun: 2008-2012. Amerika Serikat

${ }_{17}$ Ozon, Awas Jebakan Hibah Ozon, September 2000, h. 14. Beberapa perusahaan itu antara lain adalah: Jawa Fibrindo, Merah Delima, Mentari Metal Pratama, Alpine Cool, Dithone Urethan, Plysindo, Archigrama, Karya Cipta Semesta, Ferrarindo, Kulkasindo, Citaindah Jokindo, Samrow Foam, Dilihan Glory, Aneka Cool Citratama, Gaya Teknik Supply, dan lain-lain (49 perusahaan).

${ }_{18}$ Kantor Menteri Negara Lingkungan Hidup, op.cit., h. 7-41. 
ditargetkan untuk mengurangi ODS 7\%, Jepang 6\% dan Uni Eropa 8\%. ${ }^{19}$

\section{Dalam Kyoto Protocol ditetapkan} kewajiban bagi negara-negara yang terdaftar pada Annex I UN-FCCC untuk mengurangi emisi GRK secara sungguh-sungguh mulai tahun2000denganpersentaseyangditetapkan guna mencapai target tahun 2008 dan 2012. Dalam rangka untuk melaksanakan Kyoto Protocol telah dinegosiasikan di antara 180 negara penandatangan sehubungan dengan sikap Amerika Serikat yang menolak target waktu dan persentase pengurangan emisi GRK. ${ }^{20}$

Penolakan Amerika Serikat terhadap Kyoto Protocol diungkapkan menjelang diselenggarakannya COP-7 di Marrakech, Maroko pada tanggal 29 Oktober-9 November 2001. Daniel Murdiyarso mencatat:

COP7yangdiselenggarakandiMarrakesh, Maroko, pada tanggal 29 Oktober-9 November 2001 diikuti oleh lebih dari 4.400 peserta dari 172 pemerintah, 234 organisasi antarpemerintah dan nonpemerintah, dan pengamat. Sebanyak 166 kelompok media meliput acara ini. Tujuan utama COP7 adalah pertama,

${ }^{19}$ Lavanya Rajamani, op.cit., h. 127. Christiaan Vrolijk, "Quantifying the Kyoto Commitments", RECIEL, 9 (3), 2000, h. 283. Besarnya persentase untuk melakukan pengurangan emisi GRK berlaku pula pada negara-negara yang tercantum dalam Annex B Kyoto Protocol, yaitu: Australia, Austria, Belgium, Bulgaria, Canada, Croatia, Czech Republic, Denmark, Estonia, EC, Finlands, France, Germany, Greece, Hungary, Iceland, Ireland, Italy, Japan, Latvia, Liechtenstein, Lithuania, Luxemburg, Monaco, Netherlands, New Zealand, Norway, Poland, Portugal, Romania, Russian Federation, Slovakia, Spain, Sweden, Switzerland, Ukraine, UK, dan USA.

${ }^{20}$ Jochen Hauff and Fanny Missfeldt, "Should Poland Implement Domestic Emissions Trading", RECIEL, 9 (3), 2000, h. 254. Farhana Yamin, "The Kyoto Protocol: Origins, Assessment and Future Challenges", RECIEL, 7 (2), 1998, h. 113 untuk menyelesaikan persetujuan mengenai rencana terinci tentang cara-cara penurunan emisi menurut Protokol Kyoto. Kedua, untuk mencapai kesepakatan mengenai tindakan yang memperkuat implementasi Konvensi Perubahan Iklim. ${ }^{21}$

Pertemua COP-7 merupakan kelanjutan dari kegagalan pencapaian kesepakatan dalam COP-6 di Den Haag (Belanda), 13-24 November 2000. COP-6 menyerukan bahwa yang harus mengerjakan pengurangan emisi GRK tidak hanya negara berkembang (30\%) tetapi juga lebih ditekankan kepada negara maju $(70 \%) .^{22}$

Terdapat tiga tema penting dalam penerapan Kyoto Protocol yang diprioritaskan dalam forum COP-7, yaitu: ketaatan negara maju, tata guna lahan dan hutan serta mekanisme yang berkaitan dengan: "joint implementation" (Pasal 6), "clean development mechanism" (Pasal 12), dan "emission trading" (Pasal 17). Dua alasan pokok yang mendasari sikap “arogan” Amerikat Serikat dalam menolak Kyoto Protocol:

Pertama, perjanjian ini membebaskan negara berkembang dari keharusan untuk mematuhi pengurangan emisi gas rumah kaca yang dihasilkan terutama dari sisa pembakaran batu bara dan minyak bumi. Negara-negara maju tahun 1997 di Kyoto (Jepang) sepakat untuk menurunkan emisi tahun 2012 rata-rata 5,2 persen di 139.

${ }^{21}$ Daniel Murdiyarso, Sepuluh Tahun ... op.cit., h.

${ }^{22}$ Kompas, Indonesia Ingin Ratifikasi Protokol Kyoto Dipercepat, 17 November 2000. Kompas, Negara Maju Merusak Alam, 27 Oktober 2001. Edison Kurniawan, "Memantau Pola Indeks Tekanan Udara", Kompas, 28 Oktober 2002. 
bawah tingkat emisi tahun 1990. Kedua, pengurangan emisi gas rumah kaca ini bukan merupakan kepentingan ekonomi AS yang utama. ${ }^{23}$

Sikap Amerika Serikat tersebut menunjukkan pengingkarannya terhadap komitmen internasional untuk mengurangi emisi GRK yang tertuang dalam UN-FCCC. Amerika Serikat ternyata lebih mengedepankan kepentingan ekonominya sendiri daripada konsensus global dan membuktikan bahwa Amerika Serikat kurang mempedulikan persoalan pelik dunia di masa depan. ${ }^{24}$

Terhadap penolakan Amerika Serikat pada Kyoto Protocol, aktivis Greenpeace Angie Heffernan merasa "jijik dan ngeri pada Amerika Serikat" mengingat Amerika Serikat harus bertanggung jawab sebagai produsen terbesar emisi GRK yang mencapai kisaran sebesar 30\%. Penguatan mekanisme pentaatan terhadap Kyoto Protocol perlu terus diupayakan mengingat sampai saat ini target untuk mengurangi emisi GRK hingga $5 \%$ belum tercapai. ${ }^{25}$

Pada COP-6 (di Den Haag), Amerika Serikat berusaha mencari celah untuk tidak mentaati target yang ditetapkan. Percepatan ratifikasi Kyoto Protocol seperti yang diusulkan Indonesia belum mendapatkan respon positif. Kyoto Protocol akan berlaku efektifsetelah diratifikasi oleh negara-negara yang jumlah buangan emisinya minimum mencapai $55 \% .^{26}$

\footnotetext{
${ }^{23}$ Kompas, AS Tolak Protokol Kyoto, 30 Maret 2001.

${ }^{24}$ Republika, UE Setuju Protokol Kyoto Diperbaiki, 11 April 2001.

${ }^{25}$ Kompas, AS Tolak ... loc.cit.

${ }^{26}$ Kompas, Indonesia Ingin ... loc.cit. Kompas,
}

Dewasa ini Kyoto Protocol telah diratifikasi sekitar 80 negara dan kebanyakan negara berkembang yang buangan emisinya sangat rendah. Harapan yang mengemuka pada COP-6 terletak pada Uni Eropa, Rusia dan Jepang. Apabila negara-negara Uni Eropa, Rusia dan Jepang sudah meratifikasi niscaya Kyoto Protocol dapat berlaku tanpa menunggu persetujuan Amerika Serikat, karena jumlah buangan emisi sudah mencapai $55 \% .{ }^{27}$

Tanggal 31 Mei 2002 di New York, Amerika Serikat, negara-negara yang tergabung dalam Uni Eropa meratifikasi Kyoto Protocol. ${ }^{28}$ Pada WSSD 2002 di Johannesburg, Cina dan Kanada mengumumkan sebagai negara yang meratifikasi Kyoto Protocol. Rusia di arena WSSD juga mengumandangkan dukungannya pada semua substansi Kyoto Protocol. Dengan peratifikasian Kyoto Protocol oleh Rusia, maka jumlah minimum negara yang diperlukan untuk memberlakukankesepakatanyangtercantum dalam Kyoto Protocol telah terpenuhi. Mercedes Fernandez Armenteros menegaskan: “... That leaves the weight under the shoulders of the EU, Japan and Russia. The objective would be to have the Protocol Kyoto ratified and entered into force by $2002 ",{ }^{29}$

Dalam “Marrakech Agreement” (2001) diteguhkan kembali tentang maksud yang

Perlu Mekanisme Penaatan Yang Mengikat Untuk Protokol Kyoto, 23 November 2001.

27 Suara Pembaruan, Rusia Ratifikasi Protokol Kyoto, 5 September 2002. Mercedes Fernandez Armenteros, op.cit., h. 32.

${ }^{28}$ Kompas, EU Ratifikasi ... loc.cit.

${ }^{29}$ Mercedes Fernandez Armenteros, op.cit., h. 35. 
hendak dicapai para pihak dalam Kyoto Protocol: “... The aim of the parties was to reach an agreement upon the operational and technical rules for implementing the commitments on reducting emissions of greenhouse gases under the 1997 Kyoto”. ${ }^{30}$

WSSD 2002 telah menghasilkan kesepakatan bersama dari 104 kepala negara dan pemerintahan untuk mengatasi pencemaran udara yang terus menjadi permasalahan global dalam 10 tahun ke depan dan meniadakan ODS tahun 2010. ${ }^{31}$ Sebagaimana halnya dengan beberapa konsensus yang dicapai WSSD, langkah lanjutan yang dibutuhkan adalah menerapkan UN-FCCC dan Kyoto Protocol dalam tataran praktis, sehingga kedua instrumen hukum lingkungan internasional tersebut tidak sekadar komitmen belaka.

Program Lingkungan ASEAN dan LRTAP Convention (Geneva Convention, 1979)

ASEAN didirikan melalui "ASEAN Declaration" atau "Bangkok Declaration", 8 Agustus 1967. ASEAN telah menetapkan beberapa dokumen kesepakatan lingkungan regional, antara lain:

a. Manila Declaration on the ASEAN

${ }^{30}$ Ibid., h. 32. G.H. Addink, Publications About the Implementation and Enforcement of the Climate Change Convention and the Kyoto Protocol, Utrecht University, Faculty of Law, The Netherlands, t.th., h. 393. G.H. Addink, "Implementation and Enforcement of the Kyoto Protocol After Buenos Aires", Umwelt-und Technikrecht, November 1998, h. 415.

${ }^{31}$ Majalah Berita Mingguan Tempo, Dari Johannesburg: Perbaikan atau Bencana?, Edisi 9-15 September 2002, h. 48-49. Kompas, Lemah, Kompromi Mengenai Energi, 4 September 2002. Sebagai bahan tambahan: Maria Hartiningsih, "Kriminalitas di Johannesburg: Masalah Struktural, Bukan Soal Nasib", Kompas, 30 September 2002.
Environment, Manila, Philippines, 30 April 1981 yang bertujuan untuk memberikan perlindungan dan keberlanjutan lingkungan negaranegara ASEAN.

b. Jakarta Consensus on ASEAN Tropical Forestry of the Third Meeting of the ASEAN Economic Ministers on Agriculture and Forestry, 12-14 Agustus 1981, Jakarta, Indonesia yang merumuskan tentang kebijaksanaan ASEAN di bidang kehutanan.

c. ASEANDeclaration on Heritage Parks and Reserves, Bangkok, Thailand, 29 November 1984. Melalui Deklarasi ini telah dicapai kesepakatan menjalin kerjasama regional mengelola kawasan koservasi.

d. Bangkok Declaration on the ASEAN Environment, Bangkok, Thailand, 29 November 1984 yang mengimplementasikan ASEAN Development Strategy dengan “integrated approach”.

e. Joint Communique of the Second Ministrial Meeting on the Environment, Bangkok, Thailand, 29-30 November1984 sebagai tindak lanjut dari ASEAN Declaration on Heritage Parks and Reserves.

f. Agreement on the Conservation of Nature and Natural Resources (ACNNR), Kuala Lumpur, Malaysia, 9 Juli 1985. ACNNR telah diratifikasi dengan Keputusan Presiden No. 26 Tahun 1986 tentang Pengesahan ASEAN Agreement on the 
Conservation of Nature and Natural Resources, 1985 (Keppres No. 26 Tahun 1986). ACNNR menghendaki agar peraturan perundang-undangan nasional menampung kentuan yang menjamin konservasi dan pengelolaan sumber daya alam sebagai bagian integral perencanaan pembangunan.

g. Joint Press Release of the Third Ministerial Meeting on the Environment, Jakarta, Indonesia, 29-30 Oktober 1987.

h. Jakarta Resolution on Sustainable Development, Jakarta, Indonesia, 30 Oktober 1987.

i. Manila Declaration, Manila, Philippines, 15 Desember 1987.

j. Joint Press Release, Fourth ASEAN Ministerial Meeting on the Environment (AMME), Selangor, Malaysia, 18-19 Juni 1990. AMME menetapkan enam "Working Groups" ASEAN termasuk ASEAN Working Group on Transboundary Management.

k. Kuala Lumpur Accord on the Environment and Development yang dikeluarkan oleh The ASEAN Ministers for the Environment at the Fourth ASEAN Meeting of Ministers for the Environment, Kuala Lumpur, Malaysia, 19 Juni 1990.

1. Singapore Resolution on Environment and Development, Singapore, 18 Februari 1992 (SRED). SRED menegaskan tentang perlunya pengurangan emisi GRK dalam rangka mengatasi perubahan iklim dan pentingnya mengiplementasikan secara efektif "Montreal Protocol Interim Multilateral Fund".

m. Bandar Seri Begawan Resolution on EnvironmentandDevelopment, Bandar Seri Begawan, Brunei Darussalam, 26 April 1994 yang bermaksud: “. . . to establish long term goals on environmental quality and work towards harmonised environmental quality standards for the ASEAN region".

n. Informal ASEAN Ministerial Meeting on the Environment, Kuching Sarawak, Malaysia, 21 Oktober 1994.

o. Treaty on the Southeast Asia Nuclear Weapon-Free Zone, Bangkok, Thailand, 15 Desember 1995. Traktat ini telah diratifikasi Indonesia dengan Undang-undang No. 9 Tahun 1997 tentang Pengesahan Treaty on the Southeast Asia Nuclear Weapon-Free Zone (Traktat Kawasan Bebas Senjata Nuklir di Asia Tenggara). ${ }^{32}$

Dari 15 "Dokumen ASEAN" tersebut diketahui bahwa ASEAN memiliki kepedulian terhadap permasalahan lingkungan regional. Namun, ASEAN belum memberikan perhatian khusus pada aspek pengendalian pencemaran udara lintas batas. Dokumen ASEAN yang mengatur secara "sederhana" mengenai pengendalian pencemaran udara lintas batas dan pemanasan global maupun perubahan iklim adalah:

${ }^{32}$ Penyusunan ini didasarkan dan disarikan dari Koh KL. Selected ASEAN Documents on the Environment, APCEL Documents Series, Singapore, 1996, h. 6-76. 
a. Agreement on the Conservation of Nature and Natural Resources (ACNNR), 1985.

b. Jakarta Resolution on Sustainable Development (1987).

c. Joint Press Release, Fourth ASEAN Ministerial Meeting on the Environment (AMME), 1990.

d. Kuala Lumpur Accord on the Environment and Development (1990),

e. Singapore Resolution on Environment and Development (SRED), 1992, dan

f. Informal ASEAN Ministerial Meeting on the Environment (1994).

ACNNR merupakan "ASEAN document on the environment" yang bersifat "hard law" bagi Indonesia, karena telah diratifikasi melalui Keppres No. 26 Tahun 1986. ASEAN pernah mengembangkan "Environmental Programmes Plans of Actions" berupa "ASEAN Environment Programme (ASEP) of the Regional Collaborative Programme on Environment of the ASEAN Countries". Kegiatan ASEP terbagi dalam tiga tahapan: (i) Phase I: 1978-1982, (ii) Phase II: 1983-1987, dan (iii) Phase III: 1988-1992. Dalam kurun waktu tahun 1994-1998 ditetapkan "ASEAN Strategic Plan of Action on the Environment" (ASPAE). ${ }^{33}$

\section{Kebutuhan Hukum Diperlukan}

Keseluruhan "Dokumen ASEAN" maupun rencana kegiatan ASEP dan ASPAE tidak berhubungan secara langsung dengan

\footnotetext{
${ }^{33}$ Ibid., h. 133-139.
}

pengendalian pencemaran udara lintas batas. Komitmen ASEAN yang secara langsung berkaitan dengan aspek pengendalian pencemaran udara lintas batas baru tercetus pada tahun 1995 melalui "ASEAN Cooperation Plan on Transboundary Pollution” (ACPTP), Kuala Lumpur, Malaysia, Juni 1995. ACPTP berisikan tiga bidang program: (a) "transboundary atmospheric pollution", (b) "transboundary movement of hazardous wastes"; dan (c) "transboundary shipborne pollution". ${ }^{34}$

Program di bidang "transboundary atmospheric pollution” ACPTP mempunyai tujuan berikut:

a) to assess the origin and cause(s), nature and extent of local and regional haze incidents;

b) to prevent and control the sources of haze at both national and regional levels by applying environmentally sound technologies and by strengthening both national and regional capabilities in the assessment, mitigation and management of haze; and

c) to develop and implement national and regional emergency response plans. ${ }^{35}$

.Dalam Annex A ACPTP ditetapkan "National Focal Points Dealing With Atmospheric Pollution" bagi masingmasing negara ASEAN. Badan Pengendalian Dampak Lingkungan (Bapedal) adalah institusi yang ditunjuk sebagai "National

\footnotetext{
34 Ibid., h. 233.

35 Ibid., h. 234.
} 
Focal Point" Indonesia di bidang pengendalian pencemaran udara lintas batas dengan dukungan Badan Meteorologi dan Geofisika (BMG). Berdasarkan Pasal 56A Keputusan Presiden No. 2 Tahun 2002 tentang Perubahan Atas Keputusan Presiden No. 101 Tahun 2001 tentang Kedudukan, Tugas, Fungsi, Kewenangan, Susunan Organisasi, dan Tata Kerja Menteri Negara (Keppres No. 2 Tahun 2002): posisi Bapedal sebagai "National Focal Point" dengan sendirinya beralih kepada MENLH.

Kelembagaan regional yang dibentuk dalam kerangka ACPTP untuk melakukan pengendalian pencemara udara lintas batas meliputi: (i) The ASEAN Specialised Meteorological Centre (ASMC), (ii) ASEAN Institute of Forest Management (AIFM), (iii) ASEAN Working Group on Forestry, ASEAN-EC Joint Consultative Committee (JCC) Sub-Committee on Forest, dan Brunei -Indonesia-Malaysia-Philippines (BIMP). ${ }^{36}$

Beberapa negara dan lembaga "extra regional support” untuk mensukseskan ACPTPbagiupayapengendalianpencemaran udara lintas batas adalah: Amerika Serikat, Australia, Kanada, Denmark, Jepang, New Zealand, International Tropical Timber Organization (ITTO), Secretariat of the Basel Convention dan UNEP. ${ }^{37}$

ACPTP sedang diuji ketangguhannya dalam konteks pengendalian pencemaran udara lintas batas sehubungan dengan terjadinya kebakaran hutan di Indonesia. Kebakaran hutan di Indonesia yang diidentifikasi sebagai sumber utama pencemaran

\footnotetext{
36 Ibid., h. 236.

37 Ibid., h. 240-242.
}

udara lintas batas di kawasan ASEAN ternyata belum dapat ditanggulangi melalui mekanisme penerapan ACPTP yang telah dicanangkan sejak 1995. Kasus kebakaran hutan yang selalu menggejala di wilayah Sumatera dan Kalimantan mencerminkan lemahnya program "transboundary atmospheric pollution" dalam ACPTP. Hal ini mengisyaratkan kebutuhan untuk mendesak "frontier" evaluasi ACPTP demi terselenggaranya pengendalian pencemaran udara lintas batas yang efektif.

ACPTP bukanlah Dokumen ASEAN yang secara khusus memberikan perhatian terhadap pengendalian pencemaran udara lintas batas. ASEAN belum memiliki perangkat hukum lingkungan regional mengenai pengendalian pencemaran udara lintas batas sebagaimana halnya LRTAP Convention di Eropa. LRTAP Convention merupakan kesepakatan regional pertama yang telah dielaborasi menjadi kerangka kerja pengendalian pencemaran udara lintas batas secara internasional dengan masuknya Amerika Serikat dan Kanada. ${ }^{38}$

Eksistensi LRTAP Convention yang didukung delapan Protocol pelaksanaannya merupakan instrumen hukum yang dinilai efektif bagi pengendalian pencemaran udara lintas batas di Eropa. Atas dasar LRTAP Convention negara-negera Eropa menetapkan perangkat hukum pengendalian pencemaran udara yang pada umumnya difokuskan pada masalah: baku mutu udara, reduksi emisi kendaraan bermotor dan "protection of the ozone layer". ${ }^{39}$

\footnotetext{
${ }^{38}$ Alexandre Kiss and Dinah Shelton, op.cit., h. 396.

${ }^{39}$ La Ode Muhamad Syarif, op.cit., h. 101 dan Jan
} 
LRTAP Convention tidak secara langsung berkaitan dengan pengendalian pencemaran udara lintas batas di ASEAN ataupun Indonesia. Namun, kesepakatan regional yang diprakarsai Masyarakat Eropa melalui pendeklarasikan LRTAP Convention patut dikemukakan sebagai bahan pemikiran guna mempersiapkan pembuatan kesepakatan regional ASEAN yang senantiasa mengalami problem pencemaran udara lintas batas..$^{40}$

Negara-negara ASEAN seyogianya segera mempersiapkan instrumen hukum lingkungan regional mengenai pengendalian pencemaran udara lintas batas seperti LRTAP Convention. Indonesia sebagai "eksporter tahunan" asap kebakaran hutan yang dapat mengakibatkan pencemaran udara lintas batas di wilayah negara-negara tetangga diharapkan mengambil prakarsa merancang Konvensi tentang Pengendalian Pencemaran Udara Lintas Batas ASEAN ASEAN Convention on Transboundary Air Pollution (ACTAP).

\section{Daftar Bacaan}

Addink, G.H., Publications About the Implementation and Enforcement of the Climate Change Convention and the Kyoto Protocol, Utrecht University, The Netherlands, 1998.

------, General Principles of Good Governance Under GALA, Utrecht University, Utrecht, 2001.

------, Environmental Law in a Comparative Perspective: National, European and

H. Jans, European Environmental Law, European Law Publishing, Groningen, 2000, h. 359-360 dan 445-446.

${ }^{40}$ Ibid.
International Law: Literature, Utrecht University, Utrecht, 2002.

------, Norms and Enforcement of Climate Change Convention, Utrecht University, Utrecht, t.th.

Beroya, Mary Antonette A., Mengenal Lingkungan Hidup: Pedoman Untuk Memperkuat Rakyat, Yakoma-PGI, Jakarta, 2000.

Biezeveld, G.A., Duurzame Milieuwetgeving, Boom Juridische Uitgevers, Den Haag, 2002.

Blomberg, A.B., Integrale Handhaving van Milieurecht, Boom Juridische Uitgevers, de Vrije Universiteit te Amsterdam, 2000.

Boer, Ben, (ed.), Environmental Law in the South Pacific, IUCN Environmental Law Centre, United Kingdom, 1996

------, et al., International Environmental Law in the Asia Pacific, Kluwer Law International, 1998.

Boon, Foo Kim, Lye Lin Heng and Koh Kheng Lian, Environmental Protection: The Legal Framework, IUCN/APCEL/UNEP Programme, Singapore, 1997.

Cane, Peter, An Introduction to Administrative Law, Clarendon Press, Oxford, 2001.

Dix, H.M., Environmental Pollution: Atmosphere, Land, Water, and Noise, John Wiley \& Sons Ltd., Chichester, 1981.

Drupsteen, Th.G., et al., De Toekomst van de Wet Milieubeheer, Rijksuniversiteit Leiden, W.E.J. Tjeenk Willink, Deventer, 1998. 
Eade, John, (ed.), Living the Global City, Routledge, London, 1997.

Emond, D. Paul, Environmental Law: Resource Materials for the Study of Environmental Law in Indonesia and Canada, EMDI, Halifax and Jakarta, 1990.

\section{Environment Agency Japan,} Environmental Laws and Regulations in Japan, Japan, 1984.

------, Texbook for Training Course in Environmental Engineering (Air Pollution Control), Japan, 1997.

Euroconfidentiel S.A., The Rome, Maastricht and Amterdam Treaties, Belgium, 1999.

European Commission, The European Union and the Environment, Luxembourg, 1997.

------, The Customs Policy of the European Union, Luxembourg, 1999.

Faure, Michael and Gunter Heine, Environmental Criminal Law in The European Union, METRO Institute for Transnational Legal Research, Maastricht, The Netherlands, 1998.

Foque', R. en S. Gutwirth (red.), Vraagstukken van Milieurechtelijke Begripsvorming, Gouda Quint, Erasmus Universiteit Rotterdam, 2000.

Gilks, Mark, Interim Transport Plan 2000/2001, Environmental Department, London, 2001.

Hoekema, A.J., et al., Integraal Bestuur, Amsterdam University Press, Amsterdam, 1998.
Kiss, Alexandre and Dinah Shelton, Manual of European Environmental Law, Grotius Publication Cambridge University Press, Cambridge, 1997.

Lee, C.C., Dictionary of Environmental Legal Terms, McGraw-Hill, New York, USA, 1997.

Moussis, Nicholas, Guide to EU Policies, European Study Service, Belgium, 2000.

Mukono, H.J., Pencemaran Udara dan Pengaruhnya Terhadap Gangguan Saluran Pernapasan, Airlangga University Press, Surabaya, 1997.

, Prinsip Dasar Kesehatan Lingkungan, Airlangga University Press, Surabaya, 2000.

Murdiyarso, Daniel, Sepuluh Tahun Perjalanan Negosiasi Konvensi Perubahan Iklim, Penerbit Buku Kompas, Jakarta, 2003.

------, Protokol Kyoto: Implikasinya Bagi Negara Berkembang, Penerbit Buku Kompas, Jakarta, 2003.

------, CDM: Mekanisme Pembangunan Bersih, Penerbit Buku Kompas, Jakarta, 2003.

NAA, Environmental Report' 98: Creating an Eco-Airport, Vol. 3 January 1999.

Portney, Paul R. and Robert N. Stavins, Public Policies for Environmental Protection, Resources for the Future, Washington, D.C., 2000.

Proyek Pembinaan Teknis Yustisial Mahkamah Agung RI, Undangundang Nomor 23 Tahun 1997 tentang Pengelolaan Lingkungan Hidup dan Permasalahannya, Jakarta, 1998. 
Rangkuti, SitiSundari, Hukum Lingkungan dan Kebijaksanaan Lingkungan Nasional, Edisi Kedua, Airlangga University Press, Surabaya, 2000.

Susilo, F.X. Endro, Suparto Wijoyo and Ibrahim, An Overview of Indonesian Environmental Law and Comparative Aspects, Faculty of Law, Utrecht University, The Netherlands, 2002.

Syarif, La Ode Muhamad, The Implementation of International Responsibilities for Atmospheric Pollution, LEAD Indonesia-ICEL, Jakarta, 2001.

United Nations, The Earth Charter, October, 2002.
Wood, Christopher, Environmental Impact Assessment: A Comparative Review, Logman Group Limited, England, 1996.

\section{Internet Sites}

http://www.epa.gov/oar/caa/contents.html

http://europa.eu.int/comm/dg01

http://europa.eu.int/eurostat.html

http://europa.eu.int/euro

http://www.tempointeraktif.com

http://www.tempointeractive.com

http://www.kompas.com 